\title{
RESPONSE OF TWO SUNFLOWER (HELIANTHUS ANNUUS L.) GENOTYPES TO VA-MYCORRHIZAL INOCULATION AND PHOSPHORUS LEVELS
}

\author{
C.P. CHANDRASHEKARA, V.C. PATIL and M.N. SREENIVASA \\ University of Agricultural Sciences, Dharwad-580005, \\ Karnataka, India
}

\begin{abstract}
The performance of two sunflower genotypes (Morden and MSFH-8) with and without VA-mycorrhizal fungi at three $\mathrm{P}$ levels $\left(38,56\right.$ and $75 \mathrm{~kg} \mathrm{P}_{2} \mathrm{O}_{5} \mathrm{ha}^{-1}$ ) in vertisol of Dharwad was studied to determine the effect of mycorrhizal inoculation on plant growth, yield and $\mathrm{P}$ uptake. The results showed that the VAM inoculation increased sunflower yield (14\%), total biomass (16\%), oil content $(3.1 \%)$ and P uptake $(30.5 \%)$ over uninoculated control. The percent root colonization and chlamydo-spore count decreased with increasing $\mathrm{P}$ levels. The total biomass production, seed yield and $\mathrm{P}$ uptake of mycorrhizal plants at $38 \mathrm{~kg} \mathrm{P}_{2} \mathrm{O}_{5}$ ha $^{-1}$ more than the non-mycorrhizal plants at $75 \mathrm{~kg} \mathrm{P}_{2} \mathrm{O}_{5} \mathrm{ha}^{-1}$. The biomass and seed yield of mycorrhizal plants at same $\mathrm{P}$ level were more than the non-mycorrhizal plants. Mycorrhizal plants of Morden at $38 \mathrm{~kg} \mathrm{P}_{2} \mathrm{O}_{5}$ ha $^{-1}$ and MSFH-8 at 56 $\mathrm{kg} \mathrm{P}_{2} \mathrm{O}_{5}$ ha $^{-1}$ produced higher seed yield, oil content and total biomass than non-mycorrhizal plants supplied with $75 \mathrm{~kg} \mathrm{P}_{2} \mathrm{O}_{5} \mathrm{ha}^{-1}$. The results indicated that, VA-mycorrhizal inoculation helps in saving 25 and 50 percent of recommended dose of phosphatic fertilizer $\left(75 \mathrm{~kg} \mathrm{P}_{2} \mathrm{O}_{5} \mathrm{ha}^{-1}\right)$ in MSFH-8 (single cross hybrid) and Morden (open pollinated variety), respectively.
\end{abstract}

Key words: Mycorrhizas/Plant nutrition/Inoculum/Glomus fasciculatum/Helianthus annuus/Phosphorus fertilizers/Metabolism.

\section{INTRODUCTION}

The current trend is to explore the possibility of supplementing chemical fertilizers with organic ones, more particularly biofertilizers of microbial origin. In this context, VAM fungi are receiving greater attention in their beneficial effects on plant growth. Vesicular-arbuscular mycorrhizae (VAM) are widespread in soils, and often the growth of mycorrhizal plants will be higher in comparison to non-mycorrhizal plants. This beneficial effect on plant growth has largely been attributed to higher Phosphorus $(\mathrm{P})$ uptake and consequently better P nutrition of mycorrhizal plants (Sanders and Tinker 1973).

Sunflower, one of the potential oilseed crops of India has a higher P requirement. Morden (open pollinated variety) and MSFH-8 (single cross hybrid) are the two predominant genotypes of sunflower in Karnataka. VAM association have been 
reported in sunflower (Cabello 1987), and it becomes mycorrhizal as early as at two leaf stage (Iqbal and Qureshi 1977). Roots are heavily infected with Glomus macro-carpum var. geospora under greenhouse conditions (Ross and Harper 1973). The sunflower roots were more colonized in bioassay tests than love grass (Anderson and Liberia 1987).

Phosphorus is usually considered to be the major problem when VA-mycorrhizal infections are poor. High $\mathrm{P}$ levels in soil or $\mathrm{P}$ additions are known to reduce VAM colonization of roots and sporulation (Sreenivasa and Bagyaraj 1989). Studies have indicated that addition of an excess of readily available $\mathrm{P}$ eliminates beneficial mycorrhizal effects (Sreenivasa et al. 1993). Generally, research work on the use of mycorrhizae has been carried out under controlled conditions. Pot culture trials have proved substantially that sunflower responds to inoculation with efficient strains of VAM fungi at lower levels of phosphorus (Jones and Sreenivasa 1992). However, very few field experiments have been carried out so far. Hence, the present study was undertaken to study the response of two sunflower (Helianthus annuus L.) genotypes to the inoculation of VAM fungus (Glomus fasciculatum) and P levels, and to explore the possibility of substituting phosphatic fertilizer through VAM inoculation.

\section{MATERIALS AND METHODS}

A field trial was conducted at Main Research Station, University of Agricultural Sciences, Dharwad, on medium black soil ( $\mathrm{pH}$ - 7.6; organic carbon - 0.63\%; available $\mathrm{N}-0.063 \% ; \mathrm{P}_{2} \mathrm{O}_{5}-32 \mathrm{~kg} \mathrm{ha}^{-1}$ and $\mathrm{K}_{2} \mathrm{O}-295 \mathrm{~kg} \mathrm{ha}^{-1}$ ) under irrigated conditions during summer season of 1993. The experiment consisted of twelve treatments comprising three $\mathrm{P}$ levels, two levels of VAM inoculation (inoculated and un-inoculated) and two sunflower genotypes (Morden and MSFH-8) forming a 3 × 2 × 2 factorial experiment in a Randomised Complete Block Design with four replications each. Plots of size $5.0 \mathrm{~m}$ x $3.6 \mathrm{~m}$ were prepared and spacing of $45 \mathrm{~cm}$ x $20 \mathrm{~cm}$ for Morden and $60 \mathrm{~cm}$ x $20 \mathrm{~cm}$ for MSFH- 8 were followed with 200 and 150 plants per plot $\left(18 \mathrm{~m}^{2}\right)$, respectively. The recommended dose of $\mathrm{N}$ and $\mathrm{K}$ were given $\left(62.5 \mathrm{~kg}\right.$ and $51.25 \mathrm{~kg} \mathrm{ha}^{-1}$, respectively) in the form of urea and muriate of potash. The $\mathrm{P}$ levels consisted of 38,56 and $75 \mathrm{~kg} \mathrm{P}_{2} \mathrm{O}_{5} \mathrm{ha}^{-1}$ (equivalent to 50,75 and $100 \%$ of recommended dose, respectively) as single super phosphate.

Glomus fasciculatum inoculum was multiplied in sterilized sand: soil mixture (1:1 by volume) using Rhodes grass (Sreenivasa and Bagyaraj 1988). The inoculum (@ $30 \mathrm{~g} / \mathrm{spot}$ ) was placed $2 \mathrm{~cm}$ below the sunflower seeds. The inoculum consisted of colonized root fragments, hyphae and chlamydospores (126 per $50 \mathrm{~g}$ inoculum). 
Irrigation was given at IS days interval to maintain soil moisture near field capacity. Five plants were uprooted 90 (Morden) and 105 (MSFH-8) days after planting. Shoots were severed at ground level, dried at $70^{\circ} \mathrm{C}$, weighed, ground to pass a $0.5 \mathrm{~mm}$ sieve and analysed for P by Vanadomolybdate phosphoric yellow colour method (Jackson 1967). Roots were washed with water and representative fresh samples were stained with trypan blue and percent root colonization was estimated (Phillips and Hayman 1970). Chlamydospore count per $50 \mathrm{~g}$ rhizophere soil was taken by wet-sieving and decanting technique (Gerdemann and Nicolson 1963) and oil content was determined by using Nuclear Magnetic Resonance (NMR) spectrophotometer. The seed yield $\left(\mathrm{kg} \mathrm{ha}^{-1}\right)$ was computed by using net plot yield $\left(7.2 \mathrm{~m}^{2}\right)$. The data were analysed by MSTAT statistical program and least significant difference was used for mean separation.

\section{RESULTS AND DISCUSSION}

Sunflower genotypes responded well to the inoculation of VA-mycorrhizal fungi. VAM inoculation resulted in increased total biomass (16\%), seed yield (14\%) and oil content $(3.1 \%)$ (Table 1). VA- mycorrhizal fungi are associated with increased growth of many plant species, mainly through increased uptake and translocation of not only $\mathrm{P}$ but also other nutrients (Abbott and Robson 1982). In addition to P, VAM also help in uptake of Zn, $\mathrm{Cu}, \mathrm{Mn}$ and Fe etc., (Sreenivasa et al. 1993). Iqbal and Qureshi (1977) reported that mycorrhizal sunflower plants were taller, stouter, had more numerous larger leaves and bore bigger capitulum producing viable seeds than non-mycorrhizal plants. VA-mycorrhizal plants recorded 30 percent higher $\mathrm{P}$ uptake $\left(19.91 \mathrm{~kg} \mathrm{ha}^{-1}\right)$ than uninoculated plants $\left(15.25 \mathrm{~kg} \mathrm{ha}^{-1}\right)$, which ultimately enhanced the oil content of the seed. The percent root colonization and spore count was higher in mycorrhizal treatments than in uninoculated controls. Sunflower roots were heavily infected with Glomus macrocarpum var. geospora under greenhouse conditions (Ross and Harper 1973). This probably resulted in greater fungal host contact and greater uptake of nutrients and hence better plant growth and yield. Gerdemann (1964) and Daft and Nicolson (1966) correlated the increased growth and yield of crops to the extent of mycorrhizal infection.

The percent root colonization and spore count decreased with increasing P levels in both inoculated and uninoculated plants. Bagyaraj and Powell (1985) have also observed depressed VAM development at recommended P level due to higher availability of Phosphorus. In a pot culture study, Jones and Sreenivasa (1992) observed increased percent root colonization of sunflower with increase in $\mathrm{P}$ level up to $50 \%$ of recommended dose of $\mathrm{P}$, which decreased thereafter. The total bio- 
BIOTROPIA No. 8, 1995

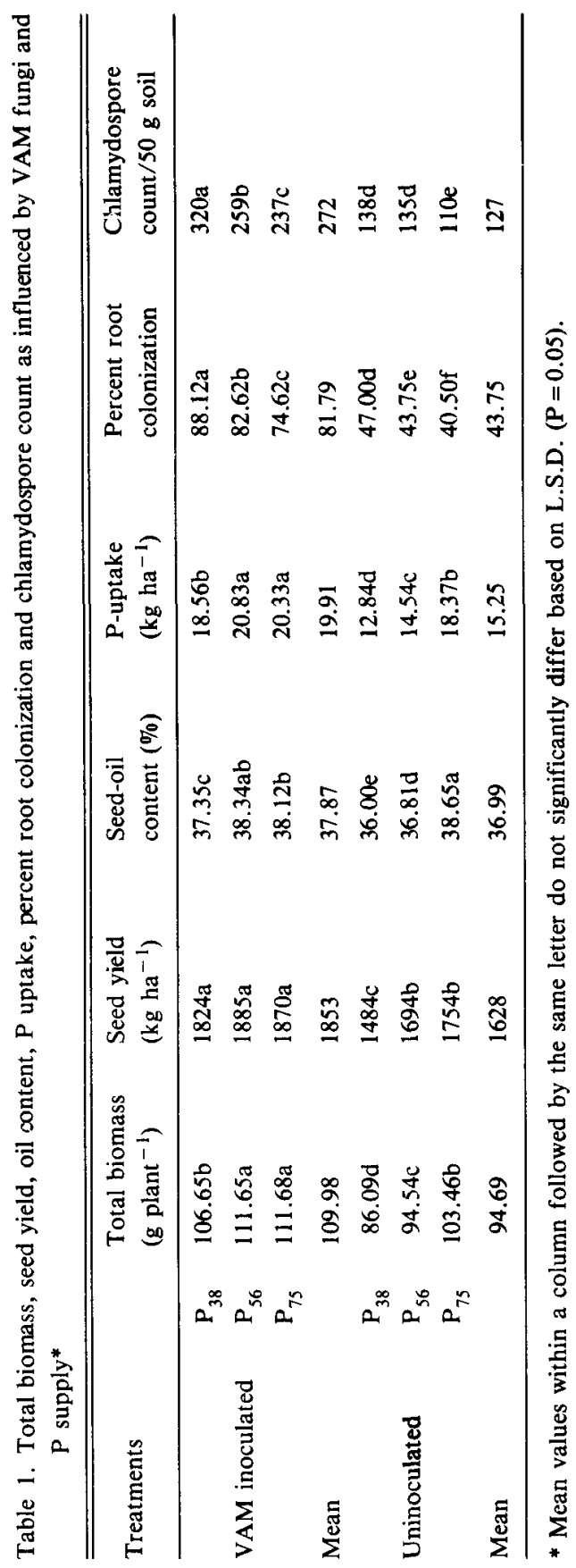


mass, seed yield and $\mathrm{P}$ uptake of mycorrhizal plants at lower Phosphorus levels (38 and $56 \mathrm{~kg} \mathrm{P}_{2} \mathrm{O}_{5}$ ha $^{-1}$ ) was more than non-mycorrhizal plants at $75 \mathrm{~kg} \mathrm{P}_{2} \mathrm{O}_{5} \mathrm{ha}^{-1}$, which may be ascribed to higher VAM-fungus root association and sporulation at lower P levels than at higher $\mathrm{P}$ level (Table 1). The total biomass, seed yield and $\mathrm{P}$ uptake of mycorrhizal plants at same $\mathrm{P}$ level was more than the non-mycorrhizal plants. The higher efficiency of VAM at lower levels of $\mathrm{P}$ has been ascribed to exploration of greater soil volume by mycorrhizal plants and faster movement of $\mathrm{P}$ ions into mycorrhizal hyphae (Bolan 1991).

Mycorrhizal plants of Morden at $38 \mathrm{~kg} \mathrm{P}_{2} \mathrm{O}_{5} \mathrm{ha}^{-1}$ and MSFH-8 at $56 \mathrm{~kg} \mathrm{P}_{2} \mathrm{O}_{5} \mathrm{ha}^{-1}$ produced higher yield, oil content and total biomass than non-mycorrhizal plants supplied with $75 \mathrm{~kg} \mathrm{P}_{2} \mathrm{O}_{5}$ ha $^{-1}$ (Table 2). This can be ascribed to the higher percent root colonization and spore count recorded with consequent increase in uptake of Phosphorus. Siqueria and Paula (1986) found low efficiency of indigenous VAM fungi. They also found maximum dry matter at $30 \mathrm{ppm}$ of $\mathrm{P}_{2} \mathrm{O}_{5}$ in mycorrhizae inoculated soybean plants as compared to 120 to $240 \mathrm{ppm}$ of $\mathrm{P}_{2} \mathrm{O}_{5}$ with native fungi. The maximum effect of VAM fungi was found at 50 and $75 \%$ of recommended dose of P in Morden and MSFH-8, respectively. Smith and Gianinazzi-Pearson (1988) found direct effect of soluble P on fungal metabolism,

Table 2. Total biomass, seed yield and oil content of sunflower genotypes as influenced by VAM fungi and $P$ supply*

\begin{tabular}{llccc}
\hline Treatments & & $\begin{array}{c}\text { Total biomass } \\
\left(\mathrm{g} \mathrm{plant}^{-1}\right)\end{array}$ & $\begin{array}{c}\text { Seed yield } \\
\left(\mathrm{kg} \mathrm{ha}^{-1}\right)\end{array}$ & $\begin{array}{c}\text { Seed-oil } \\
\text { content }(\%)\end{array}$ \\
\hline MORDEN & & & & \\
VAM Inoculated & $\mathrm{P}_{38}$ & $99.64 \mathrm{~d}$ & $1505 \mathrm{f}$ & $38.40 \mathrm{ab}$ \\
& $\mathrm{P}_{56}$ & $89.96 \mathrm{e}$ & $1350 \mathrm{~g}$ & $38.07 \mathrm{~b}$ \\
Uninoculated & $\mathbf{P}_{75}$ & $97.62 \mathrm{~d}$ & $1454 \mathrm{f}$ & $39.00 \mathrm{a}$ \\
& $\mathbf{P}_{38}$ & $73.38 \mathrm{~g}$ & $1097 \mathrm{j}$ & $36.55 \mathrm{c}$ \\
& $\mathbf{P}_{56}$ & $80.85 \mathrm{f}$ & $1246 \mathrm{~h}$ & $37.12 \mathrm{c}$ \\
MSFH-8 & $\mathbf{P}_{75}$ & $91.19 \mathrm{ed}$ & $1326 \mathrm{~g}$ & $38.90 \mathrm{a}$ \\
VAM inoculated & & & & \\
& $\mathbf{P}_{38}$ & $113.67 \mathrm{~b}$ & $2142 \mathrm{c}$ & $36.30 \mathrm{~d}$ \\
Uninoculated & $\mathrm{P}_{56}$ & $130.26 \mathrm{a}$ & $2420 \mathrm{a}$ & $38.60 \mathrm{ab}$ \\
& $\mathrm{P}_{75}$ & $125.73 \mathrm{a}$ & $2284 \mathrm{~b}$ & $37.15 \mathrm{c}$ \\
& $\mathrm{P}_{38}$ & $98.81 \mathrm{~d}$ & $1871 \mathrm{e}$ & $35.45 \mathrm{e}$ \\
& $\mathbf{P}_{56}$ & $108.23 \mathrm{c}$ & $2041 \mathrm{~d}$ & $36.56 \mathrm{c}$ \\
& $\mathrm{P}_{75}$ & $115.72 \mathrm{~b}$ & $2177 \mathrm{c}$ & $38.40 \mathrm{ab}$ \\
\hline
\end{tabular}

* Mean values within column followed by the same letter do not significantly diifier based on L.S.D. $(P=0.05)$. 
mainly by regulating enzymatic activities related to phosphate transfer to the host. Therefore, it could be noted that further increase in $\mathrm{P}$ level did not enhance growth or yield of sunflower. The relative benefits of mycorrhizal fungi decreased with increasing $\mathrm{P}$ supply.

\section{CONCLUSION}

The present study demonstrated that, the percent root colonization and spore count decreased with increasing $\mathrm{P}$ levels. The growth and yield of mycorrhizal plants at same $\mathrm{P}$ level are higher than in uninoculated plants. The differential response was obtained among the genotypes to VAM inoculation. Glomus fasciculatum was efficient at 38 and 56 $\mathrm{kg} \mathrm{P}_{2} \mathrm{O}_{5}$ ha $^{-1}$ in Morden and MSFH-8, respectively as compared to at $75 \mathrm{~kg} \mathrm{P}_{2} \mathrm{O}_{5} \mathrm{ha}^{-1}$ (100\% of recommended dose); which suggests that, VA-mycorrhizal inoculation helps in saving of 25 and 50 percent of recommended dose of phosphatic fertilizer $\left(75 \mathrm{~kg} \mathrm{P}_{2} \mathrm{O}_{5}\right.$ ha $\left.^{-1}\right)$ in MSFH-8 (single cross hybrid) and Morden (open pollinated variety), respectively.

\section{LITERATURE CITED}

ABBOTT, L.K. and A.D. ROBSON. 1982. The role of vesicular-arbuscular mycorrhizal fungi in agriculture and the selection of fungi for inoculation. Aust. J. Agric. Res. 33: 389-408.

ANDERSON, R.C. and A.E. LIBERTA. 1987. Variations in VAM relationships of two sand praharie species. AM, Midland Natural, 118 (1): 56-63.

BOLAN, N.S. 1991. A critical review of the role of mycorrhizal fungi in the uptake of phosphorus by plants. Plant soil. 134: 183-207.

BAGYARAJ, D.J. and C.LI. POWELL. 1985. Effect of vesicular-arbuscular mycorrhizal inoculation and fertilizer application on the growth of marigold. New Zealand. J. Agric. Res. 28: 169-173.

CABELLO, M.N. 1978. Vesicular-arbuscular mycorrhizae in sunflower (Helianthus annuus L.) crop. Resista. de la Facutad de Agronomia, Universidad National de la Plata, 63: 46-52.

DAFT, M.J. and J.H. NICOLSON. 1966. The effect of endogone mycorrhizae on plant growth. New Phytol. 65: 345-350.

GERDEMANN, J.W. 1964. The effect of mycorrhizae on the growth of maize. Mycologia. 56: 342-349.

GERDEMANN, J.W. and J.H. NICOLSON. 1963. Spores of endogone species extracted from soil by wet sieving and decanting. Trans. Br. Mycol. Soc. 46: 235-244.

IQBAL, J.H. and K.S. QURESHI. 1977. The effect of VAM association on growth of sunflower (Helianthus annuus) under field conditions. Biologia (Pakistan). 28: 189-196.

JACKSON, M.L. 1967. Soil chemical analysis. Prentice Hall of India (Ltd.), New Delhi.

JONES, N.P. and M.N. SREENIVASA. 1992. Response of sunflower to the inoculation of VA mycorrhiza and phosphate solubilizing bacteria in black clayey soil. J. Oilseeds Res. 10: 86-92. 
Response of two sunflower genotypes - C.P. Chandrashekara, V.C. Patil and M.N. Sreenivasa

PHILLIPS, J.M. and D.S. HAYMAN. 1970. Improved procedures for clearing roots and staining parasitic and vesicular-arbuscular mycorrhizal fungi for rapid assessment of infection. Trans. Br. Mycol. Soc. 55: 158-161.

Ross, J.P. and J.A. HARPER. 1973. Hosts of Vesicular arbuscular Endogone sp. J. Elisha Mitchell Sci. 89 (1/2): 1-3. SANDERS, F,E. and P.B. TINKER. 1973. Phosphate flow into mycorrhizal roots. Pestic. Sci. 4: 385-395.

SIQUERIA, J.O. and M.A. PAULA. 1986. Effect of VAM nutrition and phosphate use by soybean in cerado soil. Revista. Brasileria. de Gencia do solo. 10 (2): 97-102.

SMITH, S.E. and V. GIANINAZZI-PEARSON. 1988. Physiological interactions between symbionts in VAM plants. Ann. Rev. Plant Physiol. 39: 221-244.

SREENIVASA, M.N. and D.J. BACYARAJ. 1988. Chloris gayana Kunth (Rhodes grass) a better host for mass production of Glomus fasciculatum inoculum. Plant Soil. 106: 289-290.

SREENIVASA, M.N., P.U. KRISHNARAJ, G.A. GANGADHARA and H.M. MANJUNATHAIAH. 1993. Response of chilli to the inoculation of an efficient vesicular-arbuscular mycorrhizal fungus. Scientia Hortic. 53: 45-52.

SREENIVASA, M.N. and D.J. BAGYARAJ. 1989. Suitable form and level of phosphorus for mass production of VA-mycorrhizal fungus, Glomus fasciculatum. Zentralbl. Mikrobiol. 144: 33-36. 